\title{
Study of Metal Adsorbent Prepared from Guava Seeds
}

\author{
Vishal R. Parate ${ }^{1}$, Reema Gulve ${ }^{1}$, Upalee C. Labhane ${ }^{2}$, Mohammad I. Talib ${ }^{1}$ \\ ${ }^{1}$ (Department of Food Technology, University Institute of Chemical Technology, North Maharashtra University, \\ Jalgaon, India) \\ ${ }_{2}^{2}$ (Department of Chemical Technology, Dr. Babasaheb Ambedkar Technological University, Lonere, Raigad, \\ India)
}

\begin{abstract}
Guava seeds are economically cheaper and natural materials containing cellulose. The present investigation was carried out with the aim to exploit guava seeds obtained from the waste of guava processing industry for the development of metal adsorbent and to assess its ability for nickel adsorption from its aqueous solutions. The adsorbent from guava seeds was prepared by heating at $600{ }^{\circ} \mathrm{C}$ for 1 hour, followed by shaking with $1 \mathrm{~N} \mathrm{KOH}$ solution at $200 \mathrm{rpm}, 50^{\circ} \mathrm{C}$ for 4 hours. The prepared adsorbent was then characterized for various physio-chemical parameters and morphological structure. Equilibrium isotherm data for removing Ni ions by developed adsorbent was analyzed using the Langmuir, Freundlich and Temkin isotherms. It was found that Langmuir isotherms fitted well to the data than Freundlich and temkin model. In order to investigate the mechanism of sorption, kinetic data was also modeled using the pseudo first order and pseudo second order kinetic equations. It was establish that, the pseudo second order equation was the best applicable model to describe the sorption process. Thermodynamic study showed values of standard change in Gibb's free energy ( $\left.\Delta \mathrm{G}^{0}\right)$ to be negative and standard change in enthalpy $\left(\Delta \mathrm{H}^{0}\right)$ and entropy change $\left(\Delta \mathrm{S}^{0}\right)$ to be positive confirming the nature of adsorption to be endothermic, spontaneous and process to be feasible. The results revealed considerable adsorption of nickel on prepared Guava seed adsorbent and it could be economic method for the removal of nickel from aqueous solutions.
\end{abstract}

Keywords: Adsorption, Isotherms, Guava seed, Thermodynamics

\section{Introduction}

Environmental pollution is currently one of the most important issues facing humanity. It was increased exponentially in the past few years and reached alarming levels in terms of its effects on living creatures [1]. The presence of heavy metals in the environment has been of great concern because of their increased discharge, toxic nature, and other adverse effects on receiving waters. The removal of toxic heavy metals such as cadmium, copper, lead, nickel, mercury, and zinc from aqueous environment has received considerable attention in recent years due to their toxicity and carcinogenicity which may cause damage to various systems of the human body $[2,3]$.

Nickel is a toxic heavy metal that is widely used in silver refineries, electroplating, zinc base casting and storage battery industries. The chronic toxicity of nickel to humans and the environment has been well documented [4]. Nickel may cause cancer, depression, heart attacks, hemorrhage, kidney dysfunction, low blood pressure, muscle tremors, paralysis, nausea, tetanus and chest pain [5].

The most widely used methods for removing heavy metals from wastewaters include ion exchange, chemical precipitation, reverse osmosis, evaporation, membrane filtration and adsorption [6]. However, these techniques have certain disadvantages, such as high capital and operational costs or the treatment and disposal of the residual metal sludge. Adsorption compared with other methods appears to be an attractive process due to its efficiency of removing metals even if present in lower concentration [7]. The adsorption technique is also economically favorable and technically easy to separate as the requirement of the control system is minimum. A variety of functional groups present on adsorbent such as hydroxyl groups have important role in the binding processes and carboxylic groups resulting in high affinity for metal cations.

A number of agricultural materials such as moss peat, coconut husk, coir pith, rice husk, tea leaf and almond husk have been reported for the removal of toxic metals from aqueous solutions and found suitable [8]. Guava is a significant tropical fruit in Malaysia and claims superiority over other fruits by virtue of its commercial and nutritional values [9]. In the processing line, the fruit is either canned or converted into juice or puree, or used for producing jam and guava paste. Guava seeds are industrial by-products or waste of theses food processing industry. These seeds represent about $5 \%$ of the fresh fruit) [10] and are currently of no economic value [11].

The objective of the present work was to evaluate the feasibility of using the adsorbent prepared from guava seed for the removal of nickel from aqueous solution and to study its adsorption process from kinetic, Isotherm and thermodynamic standpoints. 


\section{Materials and Methods}

Guava seed was collected from Jain industry which is in Jalgaon, Maharashtra, India. The seeds were washed with double distilled water and dried in hot- air oven (Labhosp) at $105^{\circ} \mathrm{C}$ for $72 \mathrm{hr}$. [12]. Moisture, ash, fat, and crude fiber of guava seed were determined by S. Ranganna methods (1995) [13]. Protein content of guava seed was estimated by protein analyzer (Pelican Digetion-Kelplus KES 04LVA). Carbohydrate content was determined from the method described by W.O. Atwater and E.B. Rosa, 1899 [14]. Surface morphology of guava seed was analyzed by using SEM (S-4800 Type II HITACHI).

Standard nickel solution, nickel sulphate and all the other chemicals used in the study were of analytical grade with highest purity, procured from Jinendra scientific Jalgaon, Maharashtra, India. Stock solution of nickel (1000 ppm) was prepared by dissolving $4.47 \mathrm{~g}$ of Nickel sulphate [NiSO4.6H2O] in $1000 \mathrm{ml}$ double distilled.

\subsection{Preparation of Adsorbent}

The dried guava seeds were taken in Air tight stainless steel container, carbonized in a Muffle furnace at $600{ }^{\circ} \mathrm{C}$ for $1 \mathrm{hr}$. After cooling, $50 \mathrm{~g}$ of obtained carbon was poured into $1000 \mathrm{ml}$ conical flasks containing 500 $\mathrm{ml}$ of $1 \mathrm{~N} \mathrm{KOH}$ solution, and then were shaken at $200 \mathrm{rpm}$ for $4 \mathrm{hr}$. at $50^{\circ} \mathrm{C}$. The mixture was left overnight, and was then filtered to remove the sorbent. The prepared activated adsorbent was washed number of times with double distilled water to provide to neutral $\mathrm{pH}$. The adsorbent was then oven dried at $85^{\circ} \mathrm{C}$ for 2 hours $[15,16]$. It was then taken out, crushed and put into a mechanical sieve to separate the particles based on their size. Particles size $250 \mu$ pass and $150 \mu$ retained were taken for experiment.

\subsection{Characterization of Adsorbent}

The adsorbent was analyzed for moisture, ash, $\mathrm{pH}$, water soluble content and acid soluble content using CEFIC methods (1986) [17]. Bulk density was estimate by DBK 5028-7 bulk density apparatus. Sulphated ash was obtained by S. Ranganna method (1995). Yield was estimate by C.G. Joseph et al. (2007) method. Point of zero charge was determined as per method suggested by M.N. Mohamad Ibrahima [18] by using pH meter (DELUXE 101). Conductivity of adsorbent was determined by conductivity meter (Systronics 304). Fixed carbon content was calculated as per the method of A. Mohammed et al. (2012) [19]. Surface morphology of adsorbent prepared from guava seed was analyzed by using Scanning Electron Microscope (SEM) (HITACHI).

\subsection{Batch Adsorption Kinetic Studies}

To evaluate the performance of unit processes utilizing adsorption, it is necessary to have an understanding of the time dependence of the concentration distribution of the solute in both the bulk solution and solid adsorbent phases and to identify the rate-determining step. The batch kinetic and isotherm study was therefore carried out by varying initial concentrations of Ni solution $(50,75,100,150$ and $200 \mathrm{mg} / \mathrm{L})$ for various contact time $\left(15,30,60,90,120,150,180,240,300\right.$ and $360 \mathrm{~min}$.) at fixed temperatures $\left(50{ }^{\circ} \mathrm{C}\right)$, adsorbent doses $(0.5 \mathrm{~g})$, volume of metal solution $(50 \mathrm{ml})$ and $\mathrm{pH}(8.5)$. The mixtures were agitated in an orbital shaker incubator (REMI) at $200 \mathrm{rpm}$ followed by filtration using filter paper (Whatman 42). The filtrate containing the residual concentration of Nickel was determined by atomic absorption spectrophotometer (SL 176 ELICO Ltd., Hyderabad, India) at $232.0 \mathrm{~nm}$.

The $\%$ nickel removal and adsorption capacity $\mathrm{q}_{\mathrm{t}}$ (milligram per gram) at time $\mathrm{t}$ after each run was determined as follows:

$$
\begin{gathered}
\text { \% Removal of Nickel }=\frac{C_{i-} C_{e}}{C e} \times 100 \\
\mathrm{q}_{\mathrm{t}}=\frac{\left(C_{i}-C_{t}\right) V}{W} \times 100
\end{gathered}
$$

Where $C_{i}, C_{e}$ and $C_{t}$ are the concentration (mg/L) of $\mathrm{Ni}$ solution at beginning (initial), at the end adsorption (equilibrium concentration) and at the end of time t respectively, $V$ volume of solution in litre, $W$ is the weight of adsorbent $(\mathrm{g})$ [20].

The kinetics study Nickel sorption was investigated using various different models (Pseudo-first order and second-order) and the most suitable model was selected based on the linear regression correlation coefficient $\left(R^{2}\right)$ [21]. The linear form of the pseudo-first order equation used in the present is given in following equation: 


$$
\log \left(q_{e}-q_{t}\right)=\log q_{e}-\frac{K_{1}}{2.303} t
$$

Where $K_{1}$ is the pseudo-first order rate constant. $q_{e}$ is the amount of solute adsorbed on the surface of adsorbent at equilibrium and $q_{t}$ is the amount of solute adsorbed at any time $t$. The slope and intercept of the plot of $\log \left(q_{e}-q_{t}\right)$ versus $t$ helps to calculate $\mathrm{k}_{1}$ and $q_{e}$. The initial rate $(h)$ was calculated as $k_{l} q_{e}$.

The linear form of the pseudo-second order equation used in the work is given in following equation:

$$
\frac{t}{q_{t}}=\frac{1}{K_{2} q_{e} 2}+\frac{1}{q_{e}} t
$$

Where, $k_{2}$ is the rate constant of pseudo second-order adsorption. The $k_{2}$ and $q_{e}$ was determined from the slope and intercept of the plot $t / q_{t}$ versus $t$. The initial rate $(h)$ was calculated as $\mathrm{k}_{2} \mathrm{q}_{\mathrm{e}}{ }^{2}[22]$.

\subsection{Adsorption Isotherms Study}

The nature of the interaction between the adsorbate and adsorbent, i.e. favorable or unfavorable, can be determined from the isotherm shape. The data for isotherm study was taken from the kinetic studies with a time of 240 minutes at which the equilibrium was attended.

The homogenous monolayer coverage of the sorbate on a sorbent surface at a constant temperature is described by Langmuir isotherm. The Langmuir equation exploited in the study is presented in following equation.

$$
\frac{C_{e}}{q_{e}}=\frac{1}{q_{\max } K_{1}}+\frac{C_{e}}{q_{\max }}
$$

Where $q_{\max }$ is the monolayer adsorption capacity of the adsorbent $(\mathrm{mg} / \mathrm{g})$ and is the maximum amount adsorbed, $k_{I}$ is the Langmuir adsorption constant $(\mathrm{L} / \mathrm{mg}), \mathrm{c}_{e}$ is the equilibrium metal ion concentration in the solution and $q_{e}$ is the equilibrium metal ion concentration on the adsorbent. Values of $q_{\max }$ and $k_{l}$ was calculated respectively from the slope and the intercept of plot of ce $/ q_{e}$ verses $c_{e}$.

Freundlich isotherm model assumes multilayer adsorption on heterogeneous. The Freundlich behavior is indicative of the surface heterogeneity of the adsorbents, i.e. the adsorptive sites (surface of the studied adsorbents) are made up of small heterogeneous adsorption patches that are homogeneous in themselves. The activation of adsorption site takes place, leading to increased adsorption probably through the surface exchange mechanism The following Freundlich equation exercised in the work is an empirical equation that is very useful as it accurately describes much adsorption data.

$$
\log q_{e}=\log k_{f}+\frac{1}{n} \log C_{e}
$$

Where $K_{f}$ is a constant related to the adsorption capacity (Freundlich constant) and $1 / n$ is an empirical parameter related to the adsorption intensity (which varies with the heterogeneity of the material). Values of $1 / n$ and $K_{f}$ were calculated respectively from the slope and the intercept of plot of $\log q_{e} \operatorname{versus} \log c_{e}$. $[23,24]$.

Temkin model assumes effect of some indirect interactions amongst adsorbate particles and suggests linear decrease in the heat of adsorption of all the molecules in the layer, due to these interactions. Temkin linear isotherm form employed in the investigation is expressed in the following equation [25]:

$$
\begin{aligned}
& q_{e}=\frac{R T}{B} \ln \left(A C_{e}\right) \\
& q_{e}=\frac{R T}{B} \ln (A)+\frac{R T}{B} \ln \left(C_{e}\right) \\
& q_{e}=B \ln (A)+B \ln \left(C_{e}\right)
\end{aligned}
$$

Where, $B=\frac{R T}{b}, R$ is gas constant $(8.314 \mathrm{~J} / \mathrm{mol} / \mathrm{K}), T$ is Temperature $(\mathrm{K}) .1 / b$ indicates the adsorption potential of the adsorbent. The plot of $\mathrm{q}_{\mathrm{e}}$ versus $\ln \left(C_{\mathrm{e}}\right)$ enabled to determine the constants $\mathrm{A}$ and $\mathrm{B}$. 


\subsection{Thermodynamic Study}

The thermodynamic experiments were carried out using $0.5 \mathrm{~g}$ of dry adsorbent with $50 \mathrm{ml}$ of Nickel aqueous solution of $50 \mathrm{mg} / \mathrm{L}$ initial concentration, allowing sufficient time $240 \mathrm{~min}$., at varying temperature $10^{\circ} \mathrm{C}, 20^{\circ} \mathrm{C}, 30^{\circ} \mathrm{C}, 40^{\circ} \mathrm{C}, 50^{\circ} \mathrm{C}$, agitation mixtures at $200 \mathrm{rpm}$. The supernatants were filtered through Whatman 42 filter paper. The remaining Nickel concentration was analyzed using Atomic Absorption Spectrophotometer. Thermodynamic parameters such as standard change in Gibb's free energy $\left(\Delta \mathrm{G}^{0}\right)$, standard change in enthalpy ( $\left.\Delta \mathrm{H}^{0}\right)$ and standard change in entropy change $\left(\Delta \mathrm{S}^{0}\right)$.

were determined using the following equation:

$$
\begin{aligned}
& \mathrm{KD}=\frac{q_{e}}{C_{e}} \\
& \text { Where, } q_{e}=c_{i}-c_{e} \\
& \Delta \mathrm{G}^{0}=-\mathrm{RT} \ln (\mathrm{KD}) \\
& \ln (\mathrm{KD})=\left(\frac{\Delta \mathrm{S}^{0}}{R}\right)-\left(\frac{\Delta \mathrm{H}^{0}}{R T}\right)
\end{aligned}
$$

Values of $\Delta \mathrm{G}^{0}$ were calculated from the values of adsorption equilibrium constant (KD) using equations. The values of $\Delta \mathrm{H}^{0}$ and $\Delta \mathrm{S}^{0}$ were then estimated from the slope and the intercept of the linear plot of $\ln (\mathrm{KD})$ verses $1 / \mathrm{T}[26,27]$.

\subsection{Composition of Guava Seeds}

\section{Results and Discussion}

The composition of guava seeds in given in Table 1. The guava seeds were found to contain: moisture $7.1 \%$, ash $1.1 \%$ and protein $8.5 \%$. Similar type of result regarding composition of guava seeds was also obtained reported by C.R. Malacrida and N. Jorge (2013) [28]. The guava seeds were also showing fat $0.078 \%$, crude fibred $57.08 \%$ and carbohydrate $26.2 \%$. The presence of higher amount of crude fiber and other carbohydrates and lower amount of fat justify the selection of guava seeds for the present work to preparer metal absorbent was appropriate.

Table 1: Analysis Result of Guava Seeds

\begin{tabular}{|l|c|}
\hline Parameter & Value obtained \% \\
\hline Moisture & $7.1 \pm 0.29$ \\
\hline Ash & $1.1 \pm 0.23$ \\
\hline Fat & $0.078 \pm 0.06$ \\
\hline Crude fibre & $57.08 \pm 1.73$ \\
\hline Protein & $8.5 \pm 0.34$ \\
\hline Carbohydrate & $26.20 \pm 1.8$ \\
\hline
\end{tabular}

(Values are Means of 3 determinations \pm SEM)

\subsection{Characterization of Adsorbent}

Table 2 shows the result of physio-chemical analysis of prepared adsorbent. The adsorbent found to contain $2.29 \%$ moisture. The low moisture content indicates that of adsorbent had poor affinity for water. The other parameters was found to be ash $6.81 \%$, sulphated ash $4.43 \%, \mathrm{pH} 7.3$, water soluble matter $0.38 \%$, acid soluble matter $0.88 \%$ and fixed carbon $77.48 \%$. The high amount of carbon obtained with adsorbent shows that prepared adsorbent had potential to be used as material to adsorb metal. The adsorbent was showing zero point charge (pzc value) 7.4. The information about pzc helped to guess the $\mathrm{pH}$ at which the adsorbent had efficient adsorption capacity for metal ions ( $\mathrm{pH}$ above 7.4). The adsorbent was showing conductivity of $0.16 \mathrm{mS} / \mathrm{cm}$. The low bulk density of adsorbent $(0.58 \mathrm{~g} / \mathrm{L})$ signifying its porous nature. The adsorbent was showing the appreciable yield $44.74 \%$ o on the basis of raw material weight (dried guava seeds). The result of physiochemical analysis of the prepared adsorbent was in accordance with the results reported by V. Sivakumar et al., 2012 and R. Sivaraj et al., $2010[29,30]$. 
Table 2: Characterization of Prepared Adsorbent

\begin{tabular}{|l|c|}
\hline Parameter & Result \\
\hline Moisture \% & $2.29 \pm 0.17$ \\
\hline Ash \% & $6.81 \pm 0.28$ \\
\hline Sulphated ash \% & $4.43 \pm 0.23$ \\
\hline $\mathrm{pH}$ & $7.3 \pm 0.43$ \\
\hline Water soluble content \% & $0.38 \pm 0.01$ \\
\hline Acid soluble content \% & $0.88 \pm 0.17$ \\
\hline Point of zero charge & $7.4 \pm 0.23$ \\
\hline Conductivity mS/cm & $0.16 \pm 0.01$ \\
\hline Fixed carbon \% & $77.48 \pm 1.79$ \\
\hline Bulk density g/l & $0.58 \pm 0.14$ \\
\hline Yield\% & $44.74 \pm 1.26$ \\
\hline
\end{tabular}

(Values are Means of 3 determinations \pm SEM)

The essential criteria for any efficient adsorbent are its porous structure. Fig. 1 and Fig. 2 shows the surface morphology of the guava seeds and prepared adsorbent investigated by SEM. The significance difference was observed between native guava seeds and prepared adsorbent in term of porosity. The SEM image of native guava seeds was showing a highly rigid and stiffness morphology, while prepared adsorbent had porous structure. This shows that the treatments given to guava seeds (heating $+\mathrm{KOH}$ ) had beneficial effect on developing porous structure.

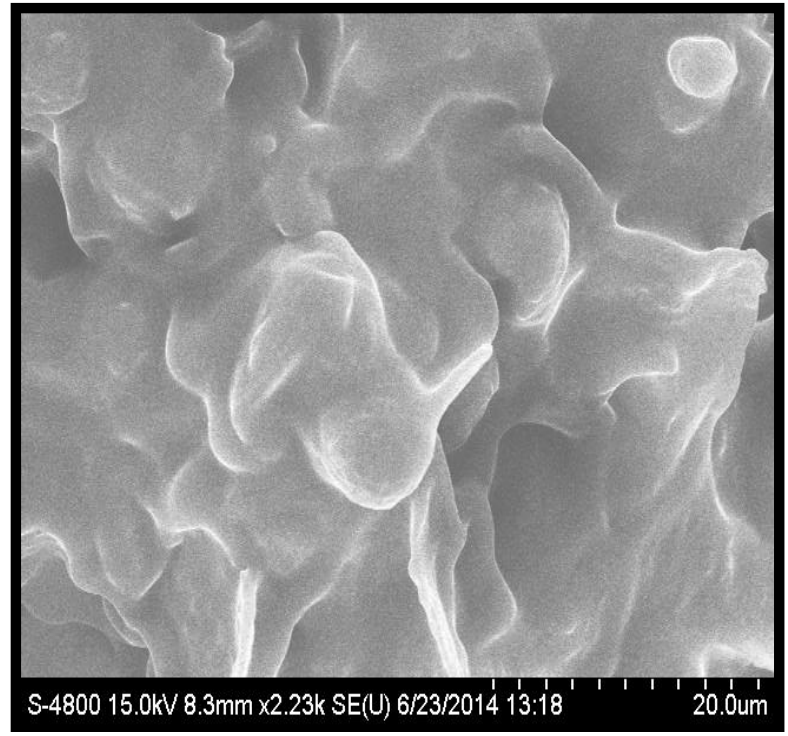

Figure 1: SEM of guava seed

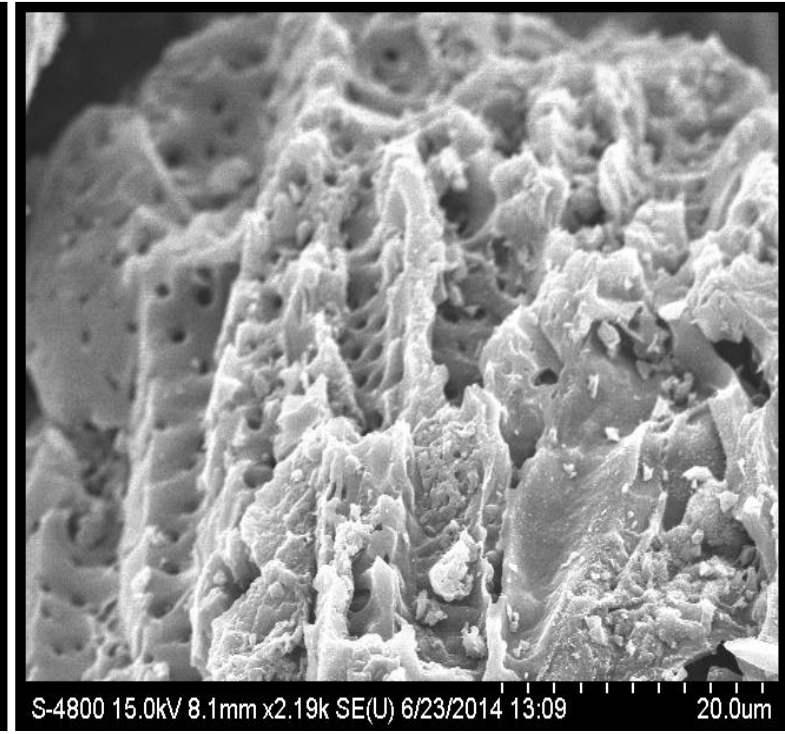

Figure 2: SEM of adsorbent

\subsection{Adsorption Kinetics}

The pseudo-second-order model (Fig. 4) yielded very good straight lines as compared to the plot of pseudo-first order (Fig. 3). The slopes and intercepts of these curves were used to determine the values of $k_{1}$ and $k_{2}$, as well as the equilibrium capacity $\left(q_{\mathrm{e}}\right)$. The calculated (cal) value of $q_{\mathrm{e}}$ (Table 3 ) from the first-order kinetics model was dramatically lower than (cal) value of $q_{\mathrm{e}}$ from the second-order kinetics model. Both $\mathrm{k}_{1}$ and $\mathrm{k}_{2}$ were found to be decreasing with increasing initial concentration of $\mathrm{Ni}$ ions solution. 


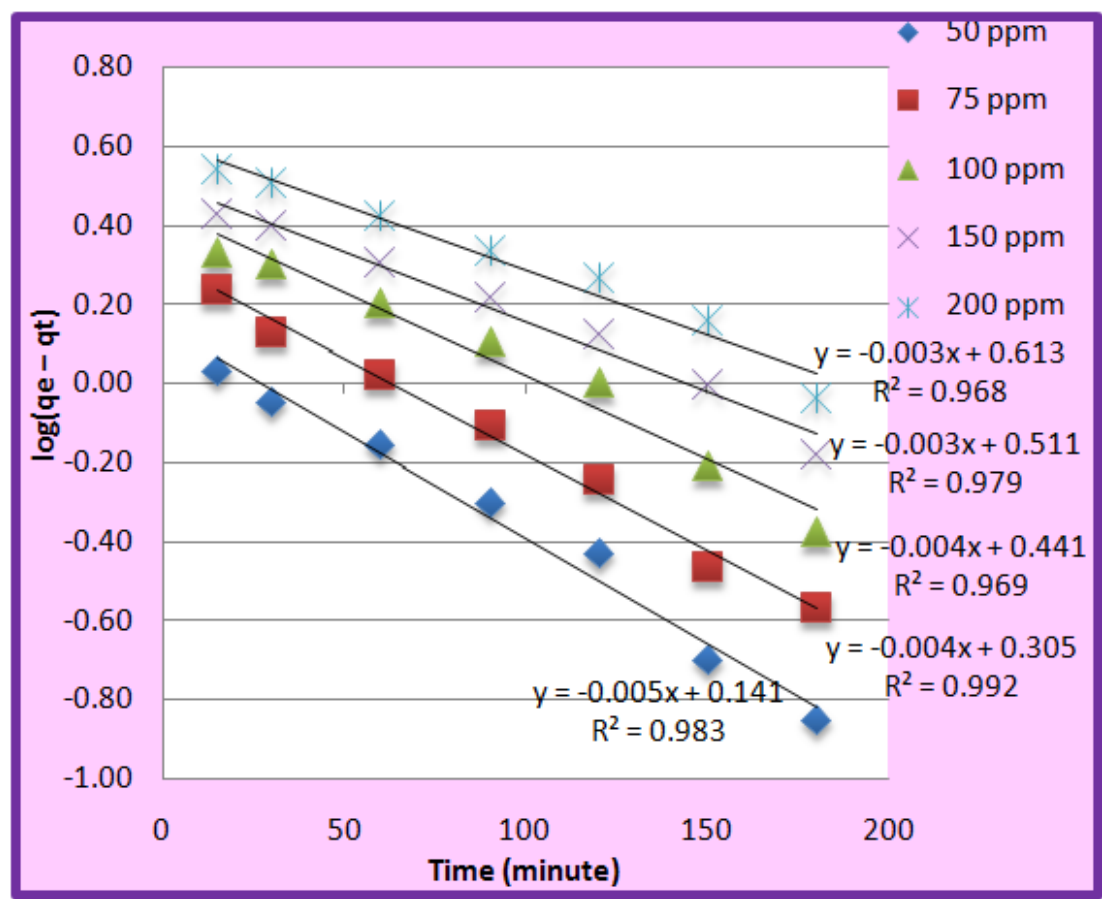

Figure 3: Pseudo-first order kinetics plot for removal of Ni ions by adsorbent (guava seed)

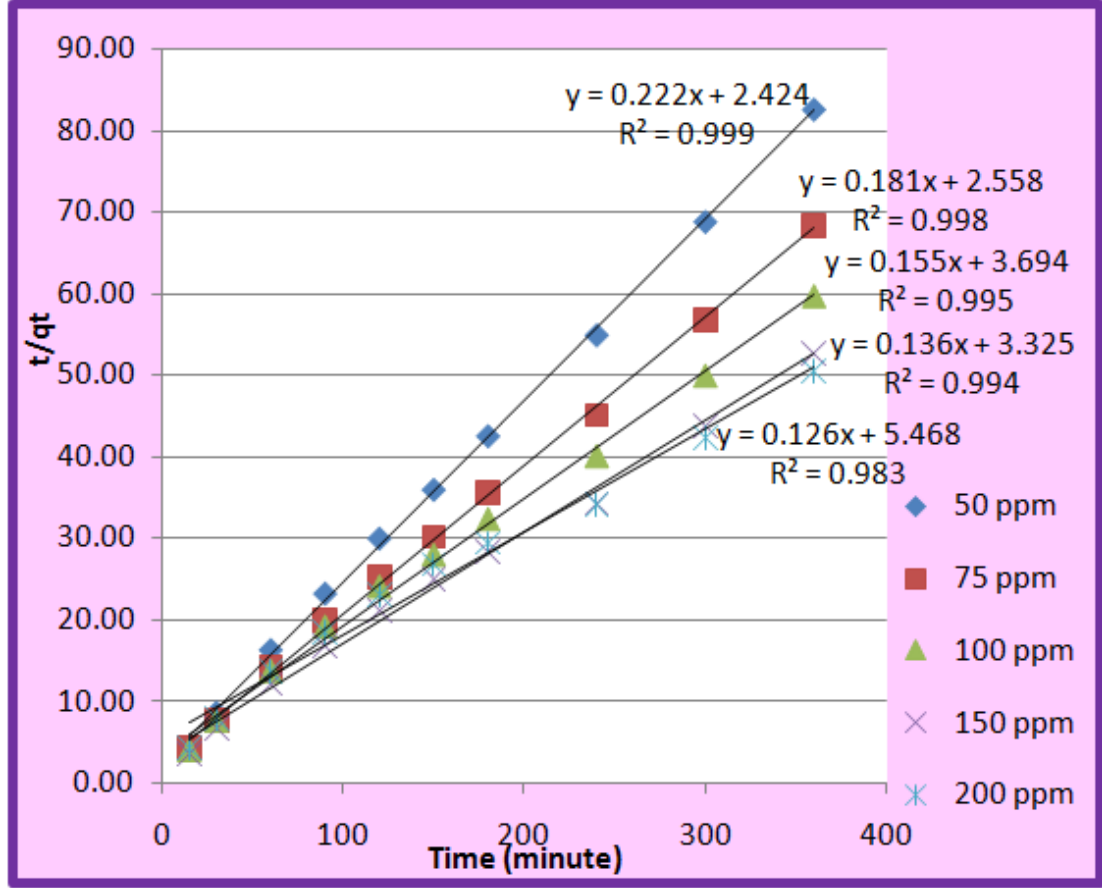

Figure 4: Pseudo-second order kinetics plot for removal of Ni ions by adsorbent (guava seed)

Table 3: Values of Kinetics Parameters for Pseudo-First-Order \& Pseudo-Second-Order Models, for Different Initial Concentration of Ni Ions Adsorption on Guava Seed Adsorbent

\begin{tabular}{|c|c|c|c|c|c|c|}
\hline \multirow{2}{*}{$\begin{array}{c}\text { Initial } \\
\text { concentration } \\
(\mathbf{m g} / \mathbf{L})\end{array}$} & \multicolumn{3}{|c|}{ First Order Kinetics } & \multicolumn{3}{c|}{ Second Order Kinetics } \\
\cline { 2 - 7 } & $\begin{array}{c}\mathrm{q}_{\mathrm{e}}(\mathrm{mg} / \mathrm{g}) \\
(\mathrm{Cal})\end{array}$ & $\begin{array}{c}K_{1} \\
\left(\mathrm{~min}^{-1}\right)\end{array}$ & $\begin{array}{c}h \\
\left(\mathrm{mg} \mathrm{g}^{-1} \mathrm{~min}^{-1}\right)\end{array}$ & $\begin{array}{c}\mathrm{q}_{\mathrm{e}}(\mathrm{mg} / \mathrm{g}) \\
(\mathrm{Cal})\end{array}$ & $\begin{array}{c}k_{2} \\
\left(\mathrm{~g} \mathrm{mg}^{-1} \mathrm{~min}^{-1}\right)\end{array}$ & $\begin{array}{c}h \\
\left(\mathrm{mg} \mathrm{g}^{-1} \mathrm{~min}^{-1}\right)\end{array}$ \\
\hline 50 & 1.383 & 0.0115 & 0.0159 & 4.504 & 0.020 & 0.412 \\
\hline 75 & 2.018 & 0.0092 & 0.0185 & 5.524 & 0.012 & 0.390 \\
\hline 100 & 2.760 & 0.0092 & 0.0253 & 6.451 & 0.006 & 0.005 \\
\hline 150 & 3.243 & 0.0069 & 0.0223 & 7.352 & 0.300 \\
\hline 200 & 4.102 & 0.0069 & 0.0283 & 7.936 & 0.002 & 0.183 \\
\hline
\end{tabular}


As the linearized pseudo-second-order kinetics model provided much better $R^{2}$ values $(0.983-0.999)$ than those for the pseudo-first-order model $\left(R^{2}: 0.968-0.992\right)$ for all the initial concentration Ni ions under consideration (50-200 $\mathrm{mg} / \mathrm{L}$ ), the adsorption of $\mathrm{Ni}$ ions on prepared adsorbent was therefore predicted to follow pseudo-second-order reaction kinetics. Fitness of experimental data well in pseudo-second-order model as compared to pseudo-first-order model was also achieved by A.K. Bhattacharya et al. (2008), E. Demirbas et al. (2004) and other investigators [31,32].

\subsection{Adsorption Isotherm}

The distribution of metal ions between the liquid phase and the solid phase can be described by several mathematical model equations such as the standard Langmuir isotherm model, the Freundlich isotherm model and Temkin isotherm model. The Langmuir model assumes that the uptake of metal ions occur on a homogenous surface by monolayer adsorption without any interaction between adsorbed ions. The fitting curves from the three isotherms along with correlation coefficient $\left(R^{2}\right)$ associated with each isotherm models is presented in Fig. 5, 6 and 7, whereas estimated models parameters is given in Table 4. It is shown that the experimental data of nickel ions adsorption on prepared adsorbent from guava seed could be well fitted by the three isotherms in order Langmuir > Freundlich > Temkin. Similar finding was also reported by H. Demiral, and G. Gunduzoglu (2010), S.N. Dash and R.C.V. Murthy and other researchers [33, 34]. Clearly, Langmuir equation provided better fitting in terms of $R^{2}$ therefore considered as the desirable model for the said metal removal system.

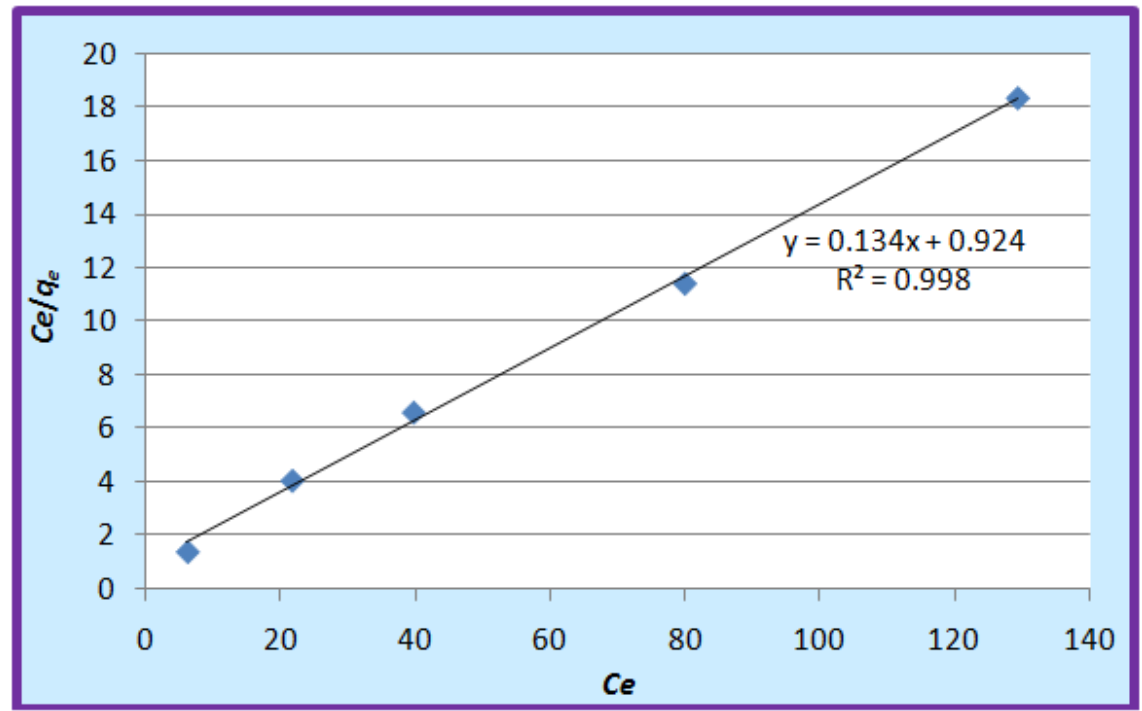

Figure 5: Langmuir adsorption isotherm plot for removal of Ni ions by adsorbent from guava seed

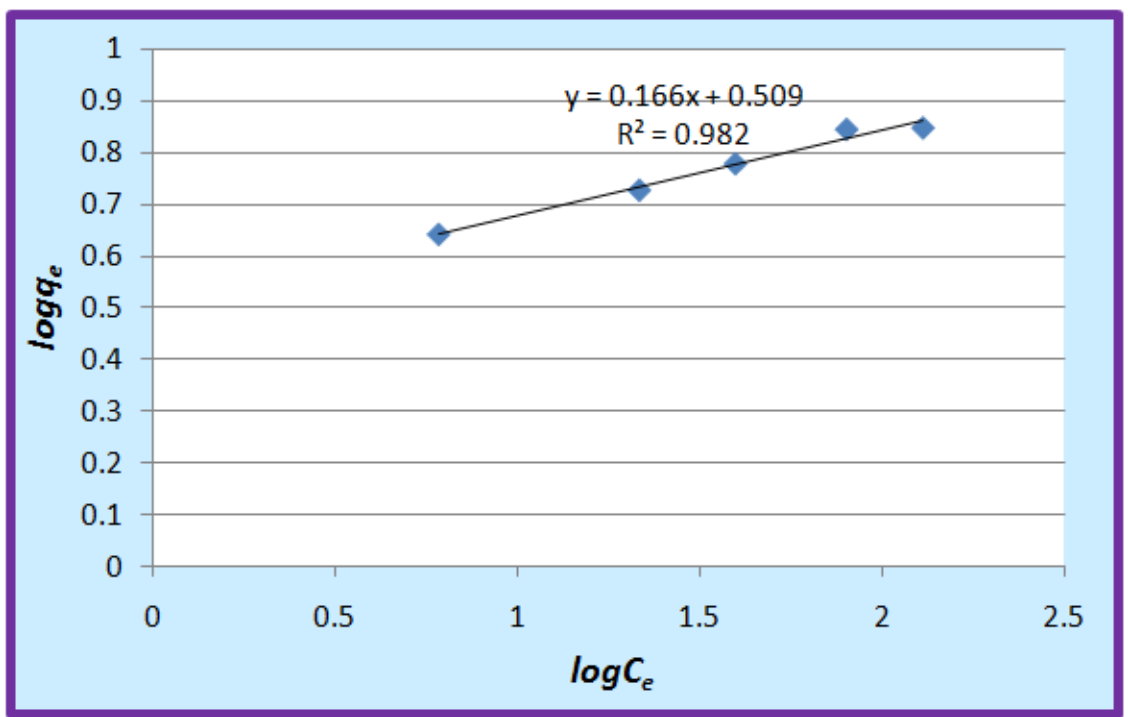

Figure 6: Freundlich adsorption isotherm plot for removal of Ni ions by adsorbent from guava seed 


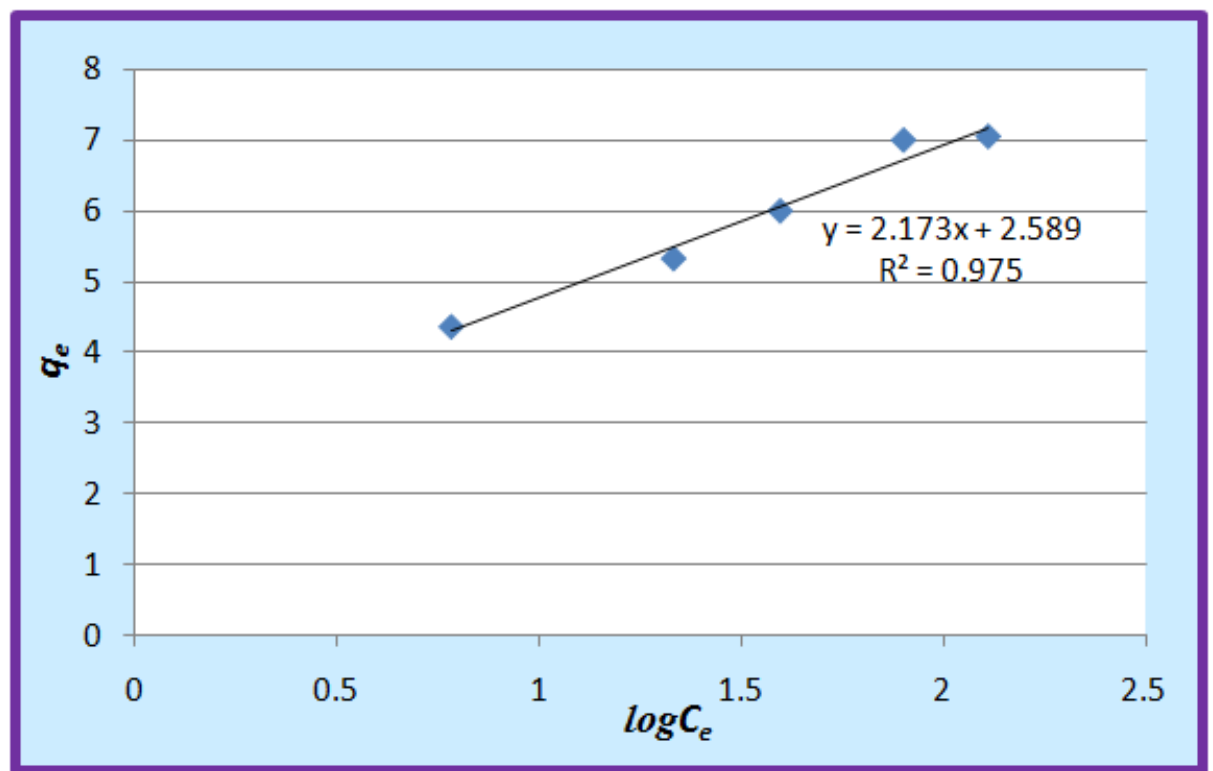

Figure 7: Temkin adsorption isotherm plot for removal of $\mathrm{Ni}$ ions by adsorbent from guava seed

Table 4: Estimated Isotherm Parameters for Ni Ions Adsorption by Adsorbent from Guava Seed

\begin{tabular}{|c|l|l|}
\hline $\begin{array}{c}\text { Langmuir } \\
\frac{C_{e}}{q_{e}}=\frac{1}{q_{\max } K_{1}}+\frac{C_{e}}{q_{\max }}\end{array}$ & Freundlich & $\begin{array}{c}\text { Temkin } \\
q_{e}=\frac{R T}{B} \ln (A)+\frac{R T}{B} \ln \left(C_{e}\right)\end{array}$ \\
\hline$R^{2}=0.998$ & $\log q_{e}=\log k_{f}+\frac{1}{n} \log C_{e}$ & $R^{2}=0.975$ \\
\hline$q_{\max }=7.46(\mathrm{mg} / \mathrm{g})$ & $R^{2}=0.982$ & $B=2.173$ \\
\hline$k_{1}=0.145(\mathrm{~L} / \mathrm{mg})$ & $k_{f}=3.22\left(\mathrm{mg} / \mathrm{g}(\mathrm{L} / \mathrm{mg})^{1 / n}\right)$ & $A=15.53(\mathrm{~L} / \mathrm{mg})$ \\
\hline- & $1 / n=0.166$ & $b=1235.81(\mathrm{~J} / \mathrm{mol})$ \\
\hline
\end{tabular}

\subsection{Adsorption Thermodynamic}

Fig. 8 is Van't Hoff plot for effect of temperature on adsorption of $\mathrm{Ni}$ ions by adsorbent that was investigated under Isothermal conditions in the temperature range of $10-50^{\circ} \mathrm{C}$. The extent of adsorption of $\mathrm{Ni}$ ions was found to be increasing with increasing temperature, indicating the process to be endothermic in nature $[35,36]$. Values of $\Delta \mathrm{G}^{0}$ were calculated from the values of adsorption equilibrium constant (KD) and is presented in Table 5. The negative values of $\Delta G^{\circ}$ confirm the feasibility of the process and the spontaneous nature of sorption with a high preference of Nickel on the adsorbent [37,38].

Table 5: Standard Gibb's Free Energy of Adsorption at Different Temperature for Ni Ions Adsorption by Adsorbent from Guava Seed

\begin{tabular}{|c|c|}
\hline $\begin{array}{c}\text { Temperature } \\
\mathbf{T}\left({ }^{(} \mathbf{K}\right)\end{array}$ & $\begin{array}{c}\Delta \mathrm{G}^{0} \\
(\square \mathbf{R T I n K D})\end{array}$ \\
\hline 283 & -3220.63 \\
\hline 293 & -3551.98 \\
\hline 303 & -3982.25 \\
\hline 313 & -4501.65 \\
\hline 323 & -5140.33 \\
\hline
\end{tabular}

The values of $\Delta \mathrm{H}^{0}$ and $\Delta \mathrm{S}^{0}$ were calculated from the slope and the intercept of the linear plot of $\mathrm{ln}$ (KD) versus $1 / \mathrm{T}$ (Fig. 8). Standard enthalpy change $\left(\Delta \mathrm{H}^{0}\right)$ and entropy change $\left(\Delta \mathrm{S}^{0}\right)$ of considered adsorption is shown in Table 6. The positive value of $\Delta \mathrm{H}^{0}$ once more confirmed adsorption of $\mathrm{Ni}$ ions onto guava seed adsorbent was endothermic in nature. The positive $\Delta S^{0}$ value validated favourable accumulation of $\mathrm{Ni}$ ions on guava seed under the prescribed condition of adsorption [39, 40]. 


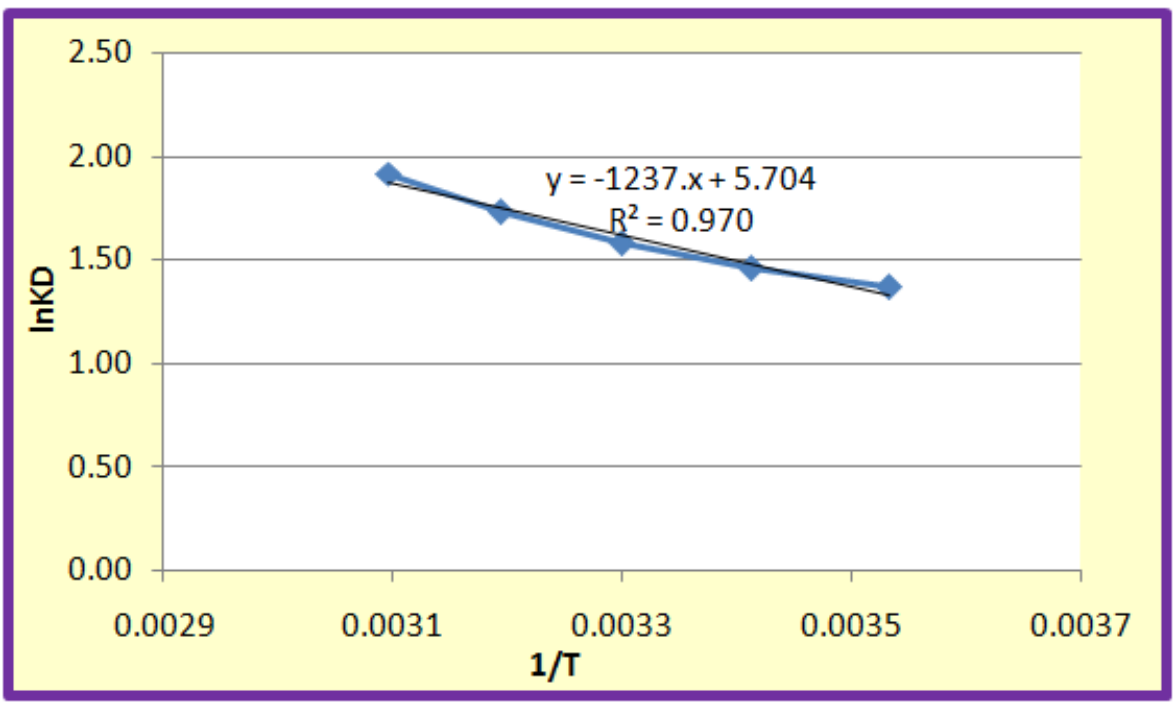

Figure 8: Van’t Hoff plot for effect of temperature on adsorption of Ni ions by adsorbent (guava seeds)

Table 6: Standard Enthalpy Change $\left(\Delta \mathrm{H}^{0}\right)$ and Entropy Change $\left(\Delta \mathrm{S}^{0}\right)$ of Adsorption for Ni Ions Adsorption by Adsorbent from Guava Seed

\begin{tabular}{|c|c|c|}
\hline Van't Hoff Equation & $\Delta \mathrm{H}^{0}(\mathrm{~J} / \mathrm{mol})$ & $\Delta \mathrm{S}^{0}(\mathrm{~J} / \mathrm{mol} \mathrm{K})$ \\
\multirow{2}{*}{$\ln (\mathrm{KD})=\left(\frac{\Delta \mathrm{S}^{0}}{R}\right)-\left(\frac{\Delta \mathrm{H}^{0}}{R T}\right)$} & 10284.42 & 47.423 \\
\cline { 2 - 3 } & & \\
\hline
\end{tabular}

\section{Conclusion}

This paper concludes by simple treatment using heat and chemical ( $\mathrm{KOH}$ solution) the guava seeds can be converted into metal adsorbent possessing property of removing Ni ions from its solution. Adsorption of Nickel ions onto prepared adsorbent from guava seed however followed the pseudo-second-order kinetic well as compare to pseudo-first-order kinetic. Also the adsorption of $\mathrm{Ni}$ ions by adsorbent was better described by the Langmuir isotherm model than the Freundlich model and Temkin model. The said adsorption was endothermic and spontaneous in nature and feasible. Based on all results, it can be concluded that the guava seed is an effective and alternative adsorbent for the removal of Nickel ions from aqueous solution because of its considerable adsorption capacity, being of natural, thus cost-effective adsorbent.

\section{References}

[1]. V. C. Renge, S. V. Khedkar, and S.V. Pande, Removal of heavy metals from wastewater using low cost adsorbent: A Review, Science. Reviews and Chemialcal Communication, 2(4), 2012, 580-584.

[2]. M. I. Kandaha, and J.L. Meunier, Removal of nickel ions from water by multi-walled carbon nanotubes, Journal of Hazardous Materials, 146(1-2), 2007, 283-288.

[3]. V. K. Gupta. Equilibrium uptake, sorption dynamics, process development, and column operations for the removal of copper and nickel from aqueous solution and wastewater using activated slag, a low-cost adsorbent, Industrial and Engineering. Chemistry Research, 37(1), 1998, 192-202.

[4]. H. Hasar, Adsorption of nickel (II) from aqueous solution onto activated carbon prepared from almond husk, Journal of Hazardous Materials B97, 2003, 49-57.

[5]. S. Amala Fatima Rani, J. R. Vimala, and T. Bhuvana, Studies on the removal of nickel(II) using chemically activated pouteriasapota seed and commercially available carbon, Der Chemica Sinica, 3(3), 2012, 613-620.

[6]. M. Kobya, E. Demirbas, E.Senturk, and M. Ince, Adsorption of heavy metal ions from aqueous solutions by activated carbon prepared from apricot stone, Bioresource Technology, 96(13), 2005, 1518-1521.

[7]. M. Bansal, D. Singh, V.K.Garg, and P. Rose, Use of agricultural waste for the removal of nickel ions from aqueous solutions:equilibrium and kinetics studies, International Journal of Environmental Science and Engineering, 1(2), 2009, 108-114.

[8]. H.Hasar, Adsorption of nickel (II) from aqueous solution onto activated carbon prepared from almond husk, Journal of Hazardou s Materials, 97(1-3), 2003, 49-57.

[9]. C.G. Joseph, A. Bono, D. Krishnaia and K.O. Soon, Sorption studies of methylene blue dye in aqueous solution by optimized carbon prepared from guava seeds (Psidium guajava L.), Material science (MEDŽIAGOTYRA), 13(1), 2007, 1392-1320.

[10]. I.A. Rahman, and B.Saad, Utilization of guava seeds as a source of activated carbon for removal of methylene blue from aqueous solution, Malaysian Journal of Chemistry, 5(1), 2003, 8-14.

[11]. K. Kaikake, K. Hoaki, H. Sunanda, R.P. Dhakal, and Y. Baba, Removal characteristics of metal ions using degreased coffee beans: Adsorption equilibrium of Cadmium (II), Bioresource Technology, 98(15), 2007, 2787-2791.

[12]. O. Abdelwahab, A. El Sikaily, A. Khaled, and A. El Nemr, Mass-transfer processes of chromium(VI) adsorption onto guava seeds, Chemistry and Ecology, 23(1), 2007, 73-85.

[13]. S. Ranganna, Handbook of analysis and quality control for fruit and vegetable product ( ${ }^{\text {nd }}$ edition TATA McGraw Hill, Publication Company ltd, New Delhi, 1995).

[14]. W.O. Atwater, and E.B. Rosa, A new respiratory calorimeter and experiments on the conservation of energy in human body II, Physical Review 9(4), 1899, 214-251. 
[15]. M.E. Argun, and S. Dursun, Removal of heavy metal ions using chemically modified adsorbents, Journal International Environmental Application \& Science, 1(1-2), 2006, 27-40.

[16]. E.-S.Z. El-Ashtoukhya, N.K.. Amina, and O. Abdelwahabb, Removal of lead (II) and copper (II) from aqueous solution using pomegranate peels as a new absorbent, Desalination, 223(1-3), 2008, 162-173.

[17]. CEFIC (European Council of Chemical Manufacturers Federation/ European Chemical Industry Council), Test methods for activated carbon, 1986, 9-43.

[18]. M.N. Mohamad Ibrahima, W.S. Wan Ngaha, M.S. Norliyana, W.R. Wan Daud, M. Rafatullah, O. Sulaiman, and R. Hashim, A novel agricultural waste adsorbent for the removal of lead (II) ions from aqueous solutions, Journal of Hazardous Materials 182(13), 2010, 377-385.

[19]. A. Mohammed, A.A. Aboje, M. Auta, and M. Jibril, A Comparative analysis and characterization of animal bones as adsorbent, Advances in Applied Science Research, 3 (5), 2012, 3089-3096.

[20]. A.K. Bhattacharya, T.K. Naiya, S.N. Mandal, and S.K. Das, Adsorption, kinetics and equilibrium studies on removal of Cr(VI) from aqueous solutions using different low-cost adsorbents, Chemical Engineering Journal, 137(3), 2008, 529-541.

[21]. A. Fernando, S. Monteiro, F.Pinto, and B.Mendes, Production of biosorbents from waste olive cake and its adsorption characteristics for $\mathrm{Zn}^{2+}$ ion, Sustainability, 1(2), 2009, 277-297.

[22]. B.M.W.P. K Amarasinghe, and R.A. Williams, Tea waste as a low cost adsorbent for the removal of $\mathrm{Cu}$ and $\mathrm{Pb}$ from wastewater, Chemical Engineering Journal 132(1-3), 2007, 299-309.

[23]. K.M.S. Surchi, Agricultural wastes as low cost adsorbents for Pb removal: kinetics, equilibrium and thermodynamics, International Journal of Chemistry 3(3), 2011, 103-112.

[24]. T.W. Weber, and R.K. Chakravarty, Pore and solid diffusion models for fixed bed adsorbers, American Institute of Chemical Engineers Journal, 20(2), 1974, 228-238.

[25]. P.S. Kumar, and K. Kirthika, Equilibrium and kinetic study of adsorption of nickel from aqueous solution on to bael tree leaf powder, Journal of Engineering Science and Technology, 4(4), 2009, 351-363.

[26]. S. Liang, X. Guo, N. Feng, and Q. Tian, Isotherms, kinetics and thermodynamic studies of adsorption of Cu2+ from aqueous solutions by $\mathrm{Mg} 2+/ \mathrm{K}+$ type orange peel adsorbents, Journal of Hazardous Materials, 174(1-3), 2010, 756-762.

[27]. Y. Nuhoglu, and E. Malkoc, Thermodynamic and kinetic studies for environmentaly friendly Ni(II) biosorption using waste pomace of olive oil factory, Bioresource Technology, 100(8), 2009, 2375-2380.

[28]. C.R. Malacrida, and N. Jorge, Fatty acid and some antioxidant compounds of psidiumguajava seed oil, Acta Alimentaria, 42(3), 2013, 371-378.

[29]. V. Sivakumar, M. Asaithambi, and P. Sivakumar, Physico-chemical and adsorption studies of activated carbon from agricultural wastes, Advances in Applied Science Research, 3(1), 2012, 219-226.

[30]. R. Sivaraj, V.Rajendran, and G.S.Gunalan, Preparation and characterization of activated carbons from parthenium biomass by physical and chemical activation techniques, E-Journal of Chemistry, 7(4), 2010, 1314-1319.

[31]. A.K. Bhattacharya, T.K. Naiya, S.N. Mandal, and S.K. Das, Adsorption, kinetics and equilibrium studies on removal of Cr(VI) from aqueous solutions using different low-cost adsorbents, Chemical Engineering Journal, 137(3), 2008, 529-541.

[32]. E. Demirbas, M. Kobya, E. Senturk, and T. Ozkan, Adsorption kinetics for the removal of chromium (VI) from aqueous solutions on the activated carbons prepared from agricultural wastes, Water SA, 30 (4), 2004, 533-539.

[33]. H. Demiral, and G. Gunduzoglu, Removal of nitrate from aqueous solutions by activated carbon prepared from sugar beet bagasse, Bioresource Technology, 101(6), 2010, 1675-1680.

[34]. S.N. Dash, and R.C.V. Murthy, Preparation of carbonaceous heavy metal adsorbent from shorearobusta leaf litter using phosphoric acid impregnation, International Journal of Environmental Science, 1 (3), 2010, 296-313.

[35]. G. Moussavi, and B. Barikbin, Biosorption of chromium(VI) from industrial wastewater onto pistachio hull waste biomass, Chemical Engineering Journal, 162(3), 2010, 893-900.

[36]. X.S. Wang, L.F. Chen, F.Y. Li, K.L. Chen, W.Y. Wan, and Y.J. Tang, Removal of Cr (VI) with wheat-residue derived black carbon: reaction mechanism and adsorption performance, Journal of Hazardous Materials, 175(1-3), 2010, 816-822.

[37]. U. Singh, B. P. Singh, and K. K. Singh, 2012. Lead removal from aqueous solutions by P. chrysosporium, Journal of Chemical and Pharmaceutical Research, 4(6):3063-3072.

[38]. H. Ye, L. Zhang, B. Zhang, G. Wu, and D. Du, Adsorptive removal of Cu(II) from aqueous solution using modified rice husk, International Journal of Engineering Research and Applications (IJERA), 2(2), 2012, 855-863.

[39]. A. Ahmad, M. Rafatullah, S. Othman, M.H. Ibrahima, Y.Y. Chiia, and B.M. Siddique, Removal of $\mathrm{Cu}(\mathrm{II})$ and $\mathrm{Pb}(\mathrm{II})$ ions from aqueous solutions by adsorption on sawdust of Meranti wood, Desalination, 247(1-3), 2009, 636-646.

[40]. A.K. Meena, G.K. Mishra, P.K. Pai, C. Rajgopal, and P.N. Nagar, Removal of heavy metal ions from aqueous solutions using carbon aerogel as an adsorbent, Journal of Hazardous Materials 122(1-2), 2005, 161-170. 